\title{
EDUCATIONAL FACILITIES NEEDS MANAGEMENT BASED ON POPULATION GROWTH PROJECTIONS JAMBI PROVINCE OF 2023
}

\author{
Zawaqi Afdal Jamil 1, Imam Arifaillah Syaiful Huda², Bayu Kurniawan³, \\ 1, 2, 3, UIN Sulthan Thaha Saifuddin Jambi
}

Jl. Jambi-Muara Bulian KM. 16 Simp. Sungai Duren Kab. Ma. Jambi

Email corresponding: zawaqi.ajdosen@uinjambi.ac.id

\begin{tabular}{|c|c|c|}
\hline Submitted: & Accepted: & Published: \\
$01-08-2021$ & $02-08-2021$ & $30-09-2021$ \\
\hline
\end{tabular}

\begin{abstract}
This study aims to develop a pattern of planning for educational facilities in the education management system in Jambi Province based on the projection of population growth in Jambi Province in 2023. The method used in this study is the quantitative method. The data collection method was carried out by literature study, and secondary data study from the Central Statistics Agency of Jambi Province. The results showed that the projected population growth in 2023 experienced different trends in each district and city. Population growth projections provide a real picture of school needs for junior high school \& senior high school. This trend indicates a strong direction of management functionalization in planning aspects for local governments to meet the needs of educational facilities junior high school \& senior high school which are relatively balanced with the population. Analysis of the results of the calculation of the number of school availability with the population in each region is relatively less balanced. This happens because one of the main factors, namely planning for school needs, is not based on information and projected data for calculating population growth in the area. The results showed that the areas that did not need to add junior high schools until 2023 were Kerinci, Merangin, Sarolangun, Batanghari, Muaro Jambi, East Tanjung Jabung, West Tanjung Jabung, Tebo, Bungo districts. On the other hand, the areas that require an additional number of junior high schools are the City of Jambi as many as 32 and the City of Sungai Penuh with 3 schools. For the senior high school, all districts in Jambi Province require additional schools. Therefore, it is suggested to the Government and Regional Governments to develop plans based on population growth projections so that there is an even distribution of educational facilities so that inequality between regions can be minimized.
\end{abstract}

Key words: population growth projections, educational facilities, management, planning

\section{Introduction}

Planning for educational facilities needs in an area needs to be carried out for equitable distribution of schools and the ratio of population to the number of school needs. In a management review, planning has an important function as a guide in carrying out activities so that they can be carried out systematically and effectively (Jamil, 2018). Therefore, in the education management review, good planning is supported by strong field data. A superior management system for planning educational facilities must require studies from various aspects such as geographical aspects, distribution and population. The development plan of an area cannot be separated from the aspect of population studies. Information on population is needed in regional planning. Based on population information, the development plan will be more accurate or on target. For this reason, population studies need to be carried out to support future development planning, both at the regional and national levels.

One aspect of population studies that can be used as a basis for planning in the management of fulfillment and distribution of educational facilities with a proportional ratio for an area is the population parameter projection. Population growth projection is a scientific calculation based on the assumption of the components of the population growth rate, namely births, deaths, and displacement. These three components determine the size of the population and the age structure of the population in the future. 
To determine each assumption, data are needed that describe trends in the past to the present, the factors that affect those components, and the relationship between one component and another as well as the targets that are expected to be achieved in the future.

Some of the benefits in calculating population projections include: 1) knowing the current state of the population, which is related to determining population policies and comparing the level of service received by the community today with the ideal level of service, 2) knowing the needs of the facilities or infrastructure needed by the community, such as the needs of schools and hospitals, and 3) knowing the effect of various events on the condition of the population in the past, present, and future.

The thinking above shows a real study in determining the planning of educational facilities needed. Planning based on the accuracy of the data possessed in deciding policies has a positive impact on the effectiveness and efficiency of the implementation of educational programs, including the fulfillment of educational facilities. On this basis in management studies, planning based on strong information and data has an urgent role in running the program.

The study described above shows that population projections have an important role in regional development planning. For this reason, it is necessary to do population projections as a basis for planning the fulfillment and distribution of educational facilities. This study presents the population growth projection of Jambi Province which is used as the basis for planning the fulfillment of educational facilities in the construction of junior and senior high schools.

Method

The method used in this study is a quantitative method. The process of searching, collecting, and analyzing data was carried out using literature studies and secondary data studies from the Central Statistics Agency of Jambi Province. Literature studies are carried out by collecting population data and analyzing various references such as scientific articles, journals, books, and academic archives that explain findings, ideas or opinions, and concepts or theories related to population projections.

The data analysis method used in this study is the geometric population projection method. The following is the formula for calculating population projections using the geometric method (Muta'ali, 2015):

Formula: $\mathrm{Pt}=\mathrm{Po}_{\mathrm{o}}(1+\mathrm{r}) \mathrm{t}$

\section{$\mathrm{Pt}$ : Total population in year $\mathrm{t}$ \\ Po: Population in the first year \\ $\mathrm{R}$ : Population growth rate \\ $\mathrm{t}$ : time}

The practical goal that is mostly done is to find out how much educational facilities are needed in each district in Jambi Province so that efforts can be made to determine further regional development policies. The following is the flow of calculating the need for educational and learning facilities in Jambi Province.

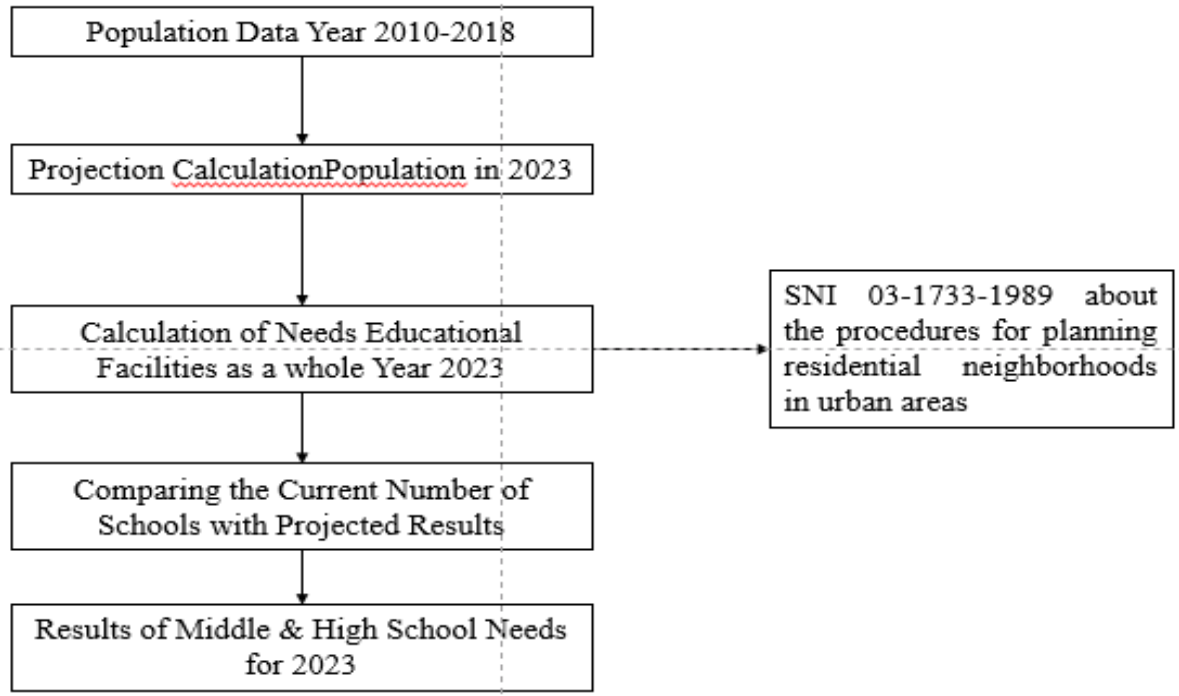

Figure 1. Flow of Calculation of Education Facility Need 


\section{Findings and Discussion}

Analysis of the needs for facilities and infrastructure, such as educational and learning facilities, will be closely related to several aspects, namely: 1 ) the population and the results of its projections, 2) the standard minimum number of requirements for the facilities in question, and 3 ) the standard space requirements for each facility/ infrastructure. This study will encourage the formation of school-based management in the management of educational units to improve the quality, efficiency, and equity of education (Setyaningsih, Suci, and Puspasari, 2021). Efforts to produce optimal results, public policies must be controlled where the design and planning process occurs; implementation through various organizations and institutions (Nugroho, 2014). Management review review, absolute management functions are carried out functionally so that the objectives of a program can run and be implemented effectively and efficiently. Management functionalization in a systematic and comprehensive manner will lead to optimizing the achievement of the desired results in the program. And vice versa if the management function is lacking or not implemented then the results of the program are not achieved according to the objectives set. One of the research results shows that the use of village fund allocations (ADD) which is not based on comprehensive information and data from various elements results in a lack of relevance of the planned program to the real needs of community development facilities (Lahada, 2018). The results of this study reflect that the planning of activities to be developed by the village government is not supported by information and data in preparing village development plans.

The results of other studies show that planning activity programs based on real information and data provides direction for the preparation of program activities in planning resulting in the achievement of effective program goals (Qarasyi, Habibah, Mus, 2021). Therefore, in planning development program activities, sources of information and data are needed as a basis for projecting trends that will occur in the future.

Effective planning efforts in the management of educational facilities, especially the procurement of school building construction, should refer to the trend of population growth in the desired area. This principle is held so that the distribution of fulfillment of educational facilities can maintain the principle of balance and justice in the ratio of population growth to school needs.

The results of the analysis of the study in calculating population growth in each region in Jambi Province were found to be relatively different. This shows signs of the need for different educational facilities. Therefore, the projected population growth in different areas will inform the policy direction for the fulfillment of educational facilities that are relatively different in each district/city in Jambi Province.

The main principle in the study of management of educational facilities, planning for the provision of educational and learning facilities must be based on predetermined standards. The standard for educational and learning facilities needs in residential areas with SNI Number 03-1733-1989 can be seen in the table below:

Table 1. Standards for Determining the Need for Education and Learning Facilities

\begin{tabular}{|c|c|c|c|c|c|c|c|c|}
\hline \multirow{2}{*}{ No. } & \multirow{2}{*}{$\begin{array}{l}\text { Type of } \\
\text { Facility }\end{array}$} & \multirow{2}{*}{$\begin{array}{c}\text { Number of } \\
\text { supporting } \\
\text { population } \\
\text { (people) }\end{array}$} & \multicolumn{2}{|c|}{$\begin{array}{l}\text { Needs per Unit of } \\
\text { Facilities }\end{array}$} & \multirow{2}{*}{$\begin{array}{l}\text { Standard } \\
\text { (m2/peo } \\
\text { ple) }\end{array}$} & \multicolumn{2}{|r|}{ Criteria } & \multirow[t]{2}{*}{ Information } \\
\hline & & & $\begin{array}{l}\text { Floor } \\
\text { Area Min. } \\
\text { (m2) }\end{array}$ & $\begin{array}{l}\text { Land } \\
\text { Area } \\
\text { Min. } \\
\text { (m2) }\end{array}$ & & $\begin{array}{l}\text { Achieve- } \\
\text { ment } \\
\text { radius }\end{array}$ & $\begin{array}{l}\text { Location and } \\
\text { solution }\end{array}$ & \\
\hline 1. & $\begin{array}{l}\text { Kinde } \\
\text { rgarte } \\
\mathrm{n}\end{array}$ & 1.250 & $\begin{array}{c}216 \\
\text { termasuk } \\
\text { rumah } \\
\text { penjaga } \\
36 \mathrm{~m} 2\end{array}$ & 500 & $0,28 \mathrm{~m} 2 / \mathrm{j}$ & $500 \mathrm{~m}^{\prime}$ & \multirow[t]{2}{*}{$\begin{array}{l}\text { In the middle of a } \\
\text { group of people. } \\
\text { Don't cross the } \\
\text { highway. } \\
\text { Join the park so } \\
\text { that there is a } \\
\text { grouping of } \\
\text { activities. }\end{array}$} & \multirow{3}{*}{$\begin{array}{l}2 \text { pre- } \\
\text { learning } \\
\text { groups @ } 60 \\
\text { students can } \\
\text { unite with } \\
\text { other } \\
\text { facilities } \\
\text { Needs must } \\
\text { be based on } \\
\text { calculations } \\
\text { with } \\
\text { formulas } 2,3 \\
\text { and } 4 \text {. } \\
\text { Can be }\end{array}$} \\
\hline 2. & $\begin{array}{l}\text { Primar } \\
\text { y } \\
\text { School }\end{array}$ & 1.600 & 633 & 2.000 & 1,25 & $1.000 \mathrm{~m}^{\prime}$ & & \\
\hline 3. & $\begin{array}{l}\text { Junior } \\
\text { High } \\
\text { School }\end{array}$ & 4.800 & 2.282 & 9.000 & 1,88 & $1.000 \mathrm{~m}^{\prime}$ & $\begin{array}{l}\text { Can be reached by } \\
\text { public } \\
\text { transportation. }\end{array}$ & \\
\hline
\end{tabular}




\begin{tabular}{|c|c|c|c|c|c|c|c|c|}
\hline 4. & $\begin{array}{l}\text { Senior } \\
\text { High } \\
\text { School }\end{array}$ & 4.800 & 3.835 & 12.500 & 2,6 & $3.000 \mathrm{~m}^{\prime}$ & $\begin{array}{l}\text { Attached to the } \\
\text { sports field. } \\
\text { It doesn't always } \\
\text { have to be in the } \\
\text { center of the } \\
\text { neighborhood. }\end{array}$ & $\begin{array}{l}\text { combined } \\
\text { with other } \\
\text { educational } \\
\text { facilities, } \\
\text { e.g. Primary } \\
\text { school, } \\
\text { junior high } \\
\text { school, }\end{array}$ \\
\hline 5. & $\begin{array}{l}\text { Readin } \\
\text { g } \\
\text { Garde } \\
\mathrm{n}\end{array}$ & 2.500 & 72 & 150 & 0,09 & $1.000 \mathrm{~m}^{\prime}$ & $\begin{array}{l}\text { In the midst of } \\
\text { groups of people } \\
\text { do not cross the } \\
\text { neighborhood } \\
\text { road. }\end{array}$ & $\begin{array}{l}\text { senior high } \\
\text { school in one } \\
\text { complex }\end{array}$ \\
\hline
\end{tabular}

Source: SNI 03-1733-1989 on Procedures for planning residential neighborhoods in urban areas

The results of calculating population growth and population projections of Jambi Province with population data for 2010-2018 obtained the results of the total needs for educational and learning facilities as follows:

\section{Population growth and population projection of Jambi Province in 2023}

The results of the calculation of population growth in Jambi Province from 11 districts show that there are 5 districts that have growth of more than 2\%, namely Sarolangun, Muara Jambi, Tanjung Jabung Barat, Tebo, and Bungo. Meanwhile, districts with population growth below $2 \%$ are Kerinci, Merangin, Batanghari, East Tanjung Jabung, Jambi City, and Sungai Penuh City.

Overall the average population growth of Jambi Province reached $1.7 \%$. The highest projected population growth is in Muara Jambi Regency with a value of $2.9 \%$. In 2023 it will reach 499,801 .

The second highest population growth is in Bungo Regency with a population of 413811 or $2.4 \%$. The data from the population projection of Jambi Province in 2023 can be seen in table 2.

Table 2. Results of the Jambi City Population Projection in 2023

\begin{tabular}{rlcccc}
\hline \multicolumn{1}{c}{ DISTRICT } & \multicolumn{2}{c}{ Total Population (Soul) } & Growth (\%/th) & $\begin{array}{c}\text { Projection of } \\
\text { Population } \\
\text { (Soul) in 2023 }\end{array}$ \\
\cline { 3 - 4 } & & 2010 & 2018 & & 243187 \\
\hline 1 & Kerinci & 229387 & 237791 & 0.4 & 416186 \\
2 & Merangin & 336050 & 383480 & 1.7 & 331949 \\
3 & Sarolangun & 245848 & 295985 & 2.3 & 289859 \\
4 & Batanghari & 240743 & 269966 & 1.4 & 499801 \\
5 & Muaro Jambi & 341588 & 432305 & 2.9 & 227508 \\
6 & Tanjung Jabung Timur & 204557 & 218413 & 0.8 & 363201 \\
7 & Tanjung Jabung Barat & 278937 & 328343 & 2.0 & 384387 \\
8 & Tebo & 298043 & 348760 & 2.0 & 413811 \\
9 & Bungo & 302558 & 367182 & 2.4 & 645340 \\
10 & Kota Jambi & 529118 & 598103 & 1.5 & 95416 \\
11 & Kota Sungai Penuh & 81789 & 89944 & 1.2 & \\
\hline
\end{tabular}

The need for education and learning

facilities in Jambi Province in 2023

The development of the population in urban areas accompanied by an increase in urbanization has brought major changes to basic human needs, namely the need for boards and their supporting facilities (Djosari et al., 2016). These basic needs continue to increase naturally along with the complexity of the needs of social life, such as the need for social activities, economic activities, and public service activities. This phenomenon demands the development of facilities and infrastructure in urban areas as a manifestation of maintaining the survival of people in urban areas in order to lead to sustainable cities.

$$
\text { Jayadinata J.T, (1999:31) in }
$$
syahriartato (2013) says that in increasing the 
development of social and economic activities, facilities and infrastructure are important. For this reason, early attention in terms of meeting the needs of facilities and infrastructure is something that is nonnegotiable in its development, both in terms of building the quantity of existing facilities and infrastructure as well as the quality of services.

The availability of educational facilities is one of the important indicators to determine the level of education in a particular area/region. In this regard, the government seeks education programs for the community both formally and informally, where informal education can be taken through courses, training and coaching. Meanwhile, for formal education, the government has provided education levels starting from Kindergarten, Elementary School, Junior High School, Senior High School and Higher Education. The study in writing this study is limited to Junior High Schools and Senior High Schools.

The following describes the results of the calculation of the population projection of Jambi Province in 2023. The number of needs for Junior High Schools (SMP) can be seen in the table below:

Table 3. Need for Junior High School in 2023

\begin{tabular}{|c|c|c|c|c|c|}
\hline \multirow[b]{2}{*}{ No. } & \multirow[b]{2}{*}{ DISTRICT } & \multirow{2}{*}{$\begin{array}{l}\text { Population } \\
\text { Projection } \\
\text { (Soul) }\end{array}$} & \multicolumn{3}{|c|}{ Junior High School } \\
\hline & & & $\begin{array}{l}\text { Number of } \\
\text { Junior High } \\
\text { School in } \\
2018\end{array}$ & $\begin{array}{c}\text { Number of Projected } \\
\text { Needs/Sufficiency of } \\
\text { Junior High School in } \\
2023\end{array}$ & Information \\
\hline 1 & Kerinci & 243187 & 77 & 26 & * \\
\hline 2 & Merangin & 416186 & 129 & 42 & * \\
\hline 3 & Sarolangun & 331949 & 117 & 47 & * \\
\hline 4 & Batanghari & 289859 & 88 & 27 & * \\
\hline 5 & Muaro Jambi & 499801 & 118 & 13 & * \\
\hline 6 & Tanjung Jabung Timur & 227508 & 78 & 30 & * \\
\hline 7 & Tanjung Jabung Barat & 363201 & 114 & 38 & * \\
\hline 8 & Tebo & 384387 & 111 & 30 & * \\
\hline 9 & Bungo & 413811 & 98 & 11 & * \\
\hline 10 & Kota Jambi & 645340 & 103 & -32 & $* *$ \\
\hline 11 & Kota Sungai Penuh & 95416 & 17 & -3 & $* *$ \\
\hline
\end{tabular}

From the results of the analysis in table 3 it can be revealed that the areas that do not require the addition of Junior High Schools until 2023 are Kerinci, Merangin, Sarolangun, Batanghari, Muaro Jambi, East Tanjung Jabung, West Tanjung Jabung, Tebo, Bungo districts. . If it is based on SNI 03-17331989 concerning Procedures for planning the housing environment in urban areas, then the junior high school in these 9 districts exceed the ideal limit, resulting in a lack of students in certain schools, while the areas that require an additional number of junior high schools are Jambi City as many as 32 and River City Full of 3 schools. This addition is based on the large population in urban areas.
At senior high schools (SMA), all districts in Jambi Province require additional schools. If referring to the ideal conditions in accordance with SNI 03-1733-1989 concerning Procedures for planning the housing environment in urban areas. In 2023, Kerinci Regency requires the addition of 19 high schools, Merangin 22, Sarolangun 4, Batanghari 11, Muaro Jambi 45, Tanjung Jabung Timur 5, Tanjung Jabung Barat 17, Tebo 19, Bungo 24, City Jambi 38, Kota Sungai Penuh 4 schools.

The projection results above lead to real management in the planning of educational facilities. Analysis of educational facilities and infrastructure needs is carried out in the planning process (Kompri, 2014). Projection of needs in management takes a 
Table 4. Need for junior high school in 2023

\begin{tabular}{llrrcr}
\hline No. & \multicolumn{1}{c}{ DISTRICT } & $\begin{array}{c}\text { Population } \\
\text { Projection } \\
\text { (Soul)2023 }\end{array}$ & $\begin{array}{c}\text { Number of } \\
\text { Senior high } \\
\text { school 2018 }\end{array}$ & $\begin{array}{c}\text { Senior High School } \\
\text { Projected Number of Senior } \\
\text { High School }\end{array}$ & Needs/Sufficiency in 2023 \\
Information \\
\hline 1 & Kerinci & 243187 & 32 & -19 & $* *$ \\
2 & Merangin & 416186 & 65 & -22 & $* *$ \\
3 & Sarolangun & 331949 & 66 & -4 & $* *$ \\
4 & Batanghari & 289859 & 50 & -11 & $* *$ \\
5 & Muaro Jambi & 499801 & 60 & -45 & $* *$ \\
6 & Tanjung Jabung Timur & 227508 & 43 & -5 & $* *$ \\
7 & Tanjung Jabung Barat & 363201 & 59 & -17 & $* *$ \\
8 & Tebo & 384387 & 62 & -19 & $* *$ \\
9 & Bungo & 413811 & 63 & -24 & $* *$ \\
10 & Kota Jambi & 645340 & 97 & -38 & $* *$ \\
11 & Kota Sungai Penuh & 95416 & 16 & -4 & $*$ \\
\hline
\end{tabular}

big role in determining the policy of meeting the needs. All these actions are of course arranged in a needs planning. Planning begins with a needs analysis carried out by analyzing and evaluating facilities and infrastructure (Nasrudin and Maryadi, 2018). Management of educational facilities and infrastructure is absolutely necessary to support the continuity of effective education (Supiana et al., 2018). In a management system perspective, the management of educational facilities andinfrastructure is an activity to fulfill educational material equipment (Rohiat, 2006).

Management of educational facilities in the functionalization of planning for educational facilities has an important role. The results show that planning based on an analysis of real educational needs will be oriented towards achieving a relatively high quality of education (Nurstalis, Ibrahim, Abdurrohim, 2021). The results of the research and some of the thoughts presented above indicate that the management of educational facilities needs must be carried out with projections that will appear in the future in order to avoid the uneven distribution of educational facilities (schools) in an area.

\section{CONCLUSION}

The results of the analysis and projections of population growth in 2023 experience different trends in each district and city. Population growth projections provide a real picture of school needs for junior high school and Senior High School levels. This trend indicates a strong direction of management functionalization in planning aspects for local governments to meet the needs of educational facilities junior high school and Senior High School which are relatively balanced with the population. Analysis of the results of the calculation of the number of school availability with the population in each region is relatively less balanced. This happens because one of the main factors, namely planning for school needs, is not based on information and projected data for calculating population growth in the area.

Therefore, the results of this study can be recommended to the Government and Regional Governments, within the framework of the management of meeting the needs of educational facilities to prepare plans based on population growth projections, to achieve equitable distribution of educational and learning facilities development so that disparities between regions can be minimized.

\section{REFERENCES}

Djosari, a., tungka, a. E., lahamendu, v., universitas, k., ratulangi, s., pengajar, s., ... bitung, k. (2016). Pembangunan prasarana dan sarana berbasis masyarakat di kelurahan pasir panjang kecamatan lembeh selatan kota bitung. Spasial, 3(3), 173-180.

Jamil, Zawaqi Afdal, Evaluasi Manajemen 
Ma'had Al-Jami'ah Perguruan Tinggi Agama Islam. Tadbir : jurnal studi manajemen pendidikan vol. 2, no. 1, juni 2018. Halaman 1-22. Doi: http: / / dx.doi.org/10.29240/jsmp.v2i1.3 50

Jayadinata, J. T. 1999. Tata Guna Tanah dalam Perencanaan Pedesaan Perkotaan \& Wilayah. Bandung: Penerbit ITB Bandung.

Kompri. 2014. Manajemen Pendidikan 1. Bandung: Alfabeta.

Lahada, Galip, Penerapan Fungsi Manajemen terhadap Kebijakan Alokasi Dana Desa Peleru Kecamatan Mori Utara Kabupaten Morowali Utara. Jurnal Ilmiah Administratie Volume: 10 Nomor : 1 Edisi : Maret 2018.

Muta'ali. 2015. Teknik Analisis Regional Untuk Perencanaan Wilayah, Tata Ruang dan Lingkungan. Yogyakarta: Badan Penerbit Fakultas Geografi Universitas Gadjah Mada

Muta'ali. 2013. Penataan Ruang Wilayah dan Kota (Tinjauan Normatif-Teknis). Yogyakarta: Badan Penerbit Fakultas Geografi Universitas Gadjah Mada.

Nugroho, D. Riant, 2014. Kebijakan Publik : Formulasi, Implementasi, dan Evaluasi. Jakarta: PT. Elex Media Komputindo.

Nasrudin dan Maryadi, Manajemen Sarana dan Prasarana Pendidikan Dalam Pembelajaran di SD. Jurnal Managemen Pendidikan - Vol. 13, No. 1, Januari 2018: 15-23.

Nurstalis, Nusi, Tatang Ibrahim, Nandang Abdurrohim. Peran Manajemen Sarana Dan Prasarana dalam Meningkatkan Mutu Pembelajaran di SMP Islam Cendekia Cianjur. Jurnal Islamic Education Manajemen 6 (1) (2021) 63-76 DOI : 10.15575/isema.v6i1.6579

Pemerintah Provinsi Jambi. 2018. Provinsi Jambi dalam angka tahun 2018.

Qarasyi, Achmad Qhuzairy, Sitti Habibah, dan Sumarlin Mus. Implementasi Rencana Kerja Tahunan Sekolah Dasar di Era New Normal. Kelola Jurnal Manajemen Pendidikan, Volume: 8, No. 1, JanuariJuni 2021, Halaman: 110-116.

Rohiat, R. (2006). Manajemen Sekolah (Teori Dasar dan Praktik). Refika Aditama.

Setyaningsih, Rini, Aisyah Nurhuda Suci, dan Feni Adriani Puspasari. Implementasi Manajemen Berbasis Sekolah (Studi di SMP Islam Al-Azhar 37 Pekanbaru). Jurnal Manajemen Pendidikan, Volume 09, No. 01, Januari 2021, halaman 18 - 23. DOI: https://doi.org/10.33751/jmp.v9i1.3363
Supiana, S., Hermawan, A. H., \& Hilmy, M. F. (2018). Manajemen Sarana Dan Prasarana Diniyah Takmiliyah. Jurnal Isema: Islamic Educational Management, 3(2), 23-41. https: / / doi.org/10.15575/isema.v3i2.500 7

Tato, 2013. Analisis Ketersediaan Sarana Permukiman Di Kawasan Tanjung Bunga Makassar, Online: https: / / syahriartato.wordpress.com/2013 /08/15/analisis-ketersediaan-saranapermukiman-di-kawasan-tanjung-bungamakassar-2/ diakses 25 Agustus 2016. 
